\title{
Thermal Performance Testing of a Flat Plate Solar Air Heater Using Optical MEASUREMENT TECHNIQUE
}

\author{
Santosh Vyas ${ }^{1}$ and Dr. Sunil Punjabi ${ }^{2}$ \\ ${ }^{1}$ Department of Mechanical Engineering, Mahakal Institute of Technology and Science, \\ Ujjain (M.P.) India \\ ${ }^{2}$ Department of Mechanical Engineering, Ujjain Engineering College, Ujjain (M.P.) India
}

\begin{abstract}
Experimental test set up at laboratory scale has been developed for thermal performance testing of flat plate solar air heater with simulated solar radiation intensity; $600 \mathrm{~W} / \mathrm{m}^{2}$. A test cell of size $1 \mathrm{~m} \times 0.5 \mathrm{~m} \times$ $0.1 \mathrm{~m}$ was fabricated. Three designs namely (i) plane absorber (ii) transverse $V$ - porous ribs and (iii) inclined V-porous ribs of absorber are tested. All the experiments are conducted with artificial solar radiation and in natural convection. Performances of these three designs have been compared on the basis of overall thermal efficiency and thermal gradient along normal to the base. Thermal gradient has been determined by laser beam deviation method. PT-100 temperature sensors have also been used to validate the optical results of thermal gradient. The overall thermal efficiencies of these designs have been found as $14.91 \%, 17.24 \%$ and $20.04 \%$ respectively. It has also been seen that thermal gradient tends to reduce with increase in efficiency.
\end{abstract}

\section{KEYWORDS}

Solar air heater, Overall thermal efficiency, Thermal gradient.

\section{INTRODUCTION}

Flat plate solar air heaters are usually applied in space heating and drying processes of agricultural products, herbal medicines, clothing etc. This system occupies an important place among solar thermal systems because of minimal use of materials. A solar air heater has low heat transfer coefficient between absorber plate and the flowing air that results in higher heat losses to the environment which ultimately leads to low thermal efficiency of such thermal systems. In order to improve the heat transfer rate a fully turbulent flow in these systems has been achieved [1]. This increases the thermal heat transfer between the absorber-plate and the fluid, which clearly improves the thermal performances of the solar collector with obstacles arranged into the air channel duct. These obstacles allow a good distribution of the fluid flow as mentioned by $\mathrm{N}$ Moummi et al [2]. There are different factors affecting the solar collector efficiency, e.g. collector geometry and dimensions, type of absorber surface, glass cover plate, air velocity etc. Increasing the absorber area or fluid flow heat-transfer area will increase the heat transfer to the flowing air on one hand and will increase the pressure drop in the collector, thus increasing the required power consumption to pump the air flow crossing the collector. A number of attempts have been made during the last 30 years to improve the thermal performance of flat plate solar air heaters by optimizing air channel depth with respect to its length or width [3]. Several methods for enhancement of thermal performance have been proposed and investigated by researchers. 


\section{NOMENCLATURE}

\begin{tabular}{|ll|}
\hline $\mathrm{q}$ & Convective heat flux \\
$\mathrm{h}$ & Convective heat transfer coefficient \\
$\mathrm{T}_{\mathrm{s}}$ & Surface temperature \\
$\mathrm{T}_{\mathrm{a}}$ & Ambient air temperature \\
$\mathrm{k}$ & Thermal conductivity \\
$\mathrm{n}$ & Refractive index \\
$\rho$ & Density of air \\
$\Delta \mathrm{y}$ & Laser beam deviation \\
$\mathrm{L}$ & laser beam path length \\
& Overall thermal efficiency $=\frac{m c_{p}\left(T_{o}-T_{i}\right)}{I A_{c}} \times 100 \%$ \\
$\eta$ & \\
$\mathrm{T}_{\mathrm{o}}$ & Outlet temperature of air \\
$\mathrm{T}_{\mathrm{i}}$ & Inlet temperature of air \\
$\mathrm{m}$ & Air mass flow rate \\
$\mathrm{c}_{\mathrm{p}}$ & Specific heat of air at atmospheric pressure \\
$\mathrm{I}$ & Intensity of artificial solar radiation \\
$\mathrm{A}_{\mathrm{c}}$ & Top cover collector area of solar air heater \\
\hline
\end{tabular}

Most of the testing methods used are intrusive in which probes are inserted in the flow field. It leads to distortion in flow field. Non-intrusive optical techniques like interferometry, schlieren photography and shadowgraphy are more effective in obtaining accurate results. Unlike intrusive techniques no sensor or probe is inserted in the flow field rather a optical beam is projected through the flow field without any distortion and deviation in the results. In this one of such non intrusive techniques has been applied for performance testing of solar air heater. Rajendra Karwa et al [4] have performed a comparative study on various types of roughness geometries proposed for solar air heater ducts. Study has shown that the integral chamfered with groove roughness is the most preferred one. Vishvajeet Singh Hans et al [5] have investigated heat transfer and friction characteristics of a multiple v-rib roughness solar air heater. Aluminium wires of circular cross section were used for creating roughness on the underside of the absorber plate. The thermal performance of multiple v-rib roughened solar air heaters is better than that of single V-rib roughened solar air heater. Considerable improvement in thermo hydraulic performance of solar air heater roughened with multiple V-ribs has been observed. Prabha Chand and S.P. Sharma [6] have given a theoretical model for air temperature rise and hence efficiency to investigate the thermal performance characteristics of solar air heater having wavy fins on absorber plate. The effect of area enhancement factor, fin spacing and mass flow rate on thermal performance has been presented and results are compared with plain fins and without fins. Performance of flatplate solar air heaters is enhanced by providing wavy fins on the absorber plate and this enhancement is a strong function of area enhancement factor, fin spacing and mass flow rate. A substantial enhancement in thermal efficiency of $43 \%$ and $61 \%$ has been found at mass flow rate of $0.0111 \mathrm{~kg} / \mathrm{s}$ when the fin spacing decreases from $4.0 \mathrm{~cm}$ to1.0cm.Turhan Koyuncu [7] tested and analysed six different models of natural circulation air heating solar collectors for their performance. Each collector mainly consisted of a frame constructed from hardboard, vent holes, hardboard insulation, absorbing surface made of black coated aluminium sheet and clear plastic glazing. Among six models the model with the single plastic glazing, black painted flat plate absorber and front-pass was found most efficient. N. Moummi et al [8] have studied the effect of rectangular plate fins inserted perpendicular to the air flow in solar air heater. The fluid flows out through the interstices between fins in the same row; this allows a good distribution of the fluid and reduces the dead zones. Hikmet Esen [9] presented an experimental analysis of novel flat plate solar air heater with several obstacles and without obstacles. Increasing the available heat- 
transfer area may be achieved if air is flowing simultaneously and separately over and under the different obstacle absorbing plates instead of only flowing either over or under the different obstacle absorbing plates, leading to improved collector efficiency. Foued Chabane et al [10] presented an experimental investigation on thermal performance of a single pass solar air heater with fins attached. Longitudinal fins were used inferior to the absorber plate to increase the heat exchange and render the flow fluid in the channel uniform. Experiments were performed for an air mass flow rate of $0.012 \mathrm{~kg} / \mathrm{s}$. Maximum efficiency of $40.02 \%$ was obtained by using five longitudinal fins for the flow rate of $0.012 \mathrm{~kg} / \mathrm{s}$. Arun Venu et al [11] incorporated porous medium to improve the thermal performance of a dual purpose solar collector. Dual purpose solar collectors can be used for heating air and water simultaneously using incident solar radiation resulting in optimum usage of energy and space. The porous matrix is incorporated below the absorber plate of the collector to improve the thermal performance of the overall system. Comparison of the proposed dual purpose solar collector with an existing design clearly indicates the advantage of incorporating the porous medium in terms of enhanced heat delivery and thermal efficiency. Ben Slama Romdhane [12] has made attempt for creation of turbulence in the air channels by using obstacles or baffles.

An indoor experimental test set-up, has been designed, fabricated and tested in Mechanical Engineering department of Ujjain Engineering College, Ujjain. The efficiency of the solar air heater is determined from the experimental measurements. The influence of various parameters, such as the obstacles of absorber plate and the mass flow rate of air are examined. Thermal gradient at a particular location inside the solar air heater was also determined optically using $10 \mathrm{~mW}$ He-Ne laser beam (coherent source) and also by using RTD-PT100 temperature sensors.

\section{DESCRIPTION OF EXPERIMENTAL TEST SET -UP}

An indoor experimental set up (figure 1) has been developed for testing of flat plate solar air heater using the concept of testing solar application under indoor simulated environment from investigation performed by S.C. Solanki et al [13] for testing of photovoltaic (PV/T) air collectors. Schematic view of solar air heater (test cell) is shown in figure 2. It consists of rectangular box made from $18 \mathrm{~mm}$ thick plywood of size with internal dimensions of $1 \mathrm{~m} \mathrm{x} 0.5 \mathrm{~m} \mathrm{x}$ $0.1 \mathrm{~m}$.

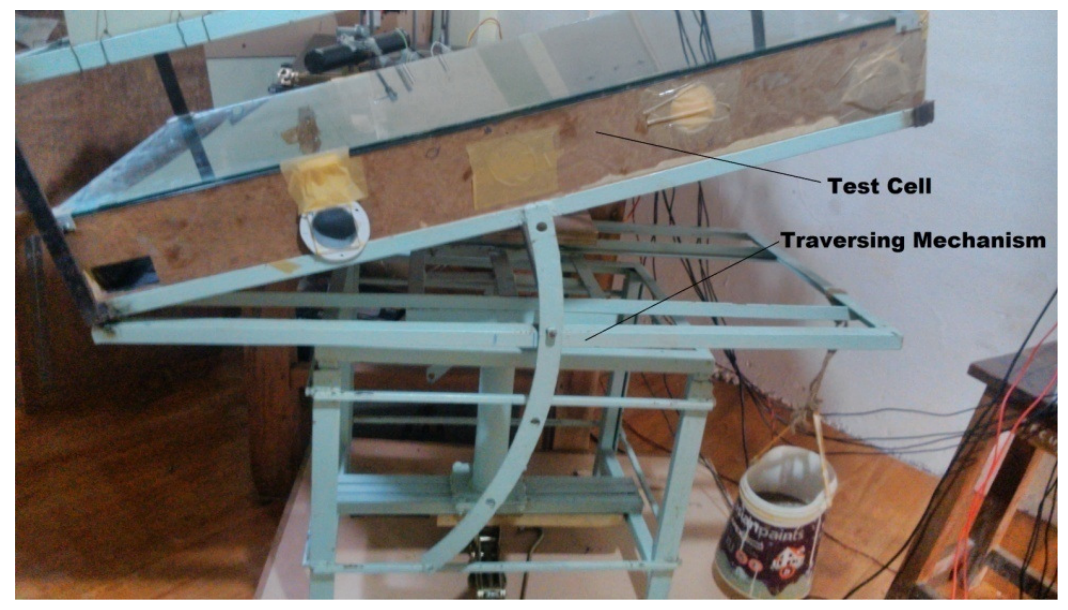

Figure 1. Experimental test set up 
The base of the box is fitted with $1 \mathrm{~mm}$ thick blackened aluminium sheet. Test cell is covered with $5 \mathrm{~mm}$ thick toughened plain transparent glass from the top. Toughened glass can withstand high temperature around $100^{\circ} \mathrm{C}$ without mechanical failure. Ambient air will made to flow through the passage between transparent glass and absorber surface. Side walls were not covered with aluminium sheet in order to achieve adiabatic conditions at all the sides so as to observe the effect of base only. Rectangular openings two for air inlet and two for air outlet of sizes $76 \times 41 \mathrm{~mm}^{2}$ and $130 \times 73 \mathrm{~mm}^{2}$ respectively are provided. A pair of rectangular slots of $50 \mathrm{~mm}$ width is provided on opposite longer side walls for attaching a pair of optical windows at a distance of $31 \mathrm{~cm}$ from the inlet air openings. Laser beam can be projected in short beam length through the test cell during the experimentation for determining thermal gradient.

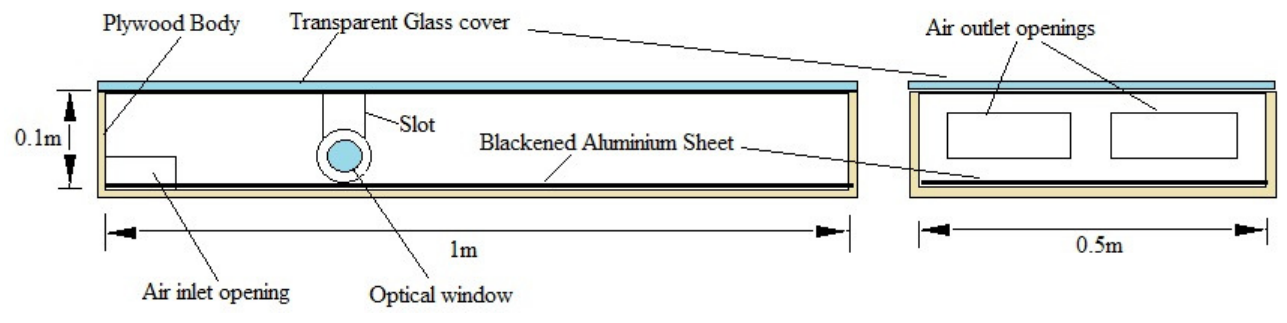

Figure 2 Front and side views of solar air heater (test-cell)

A traversing mechanism of mild steel angular bars has also been designed and fabricated that can hold the test cell during experimentation (figure 1). This mechanism is designed to move the test cell in vertical direction with a simple screw jack and to rotate about vertical and horizontal axes so that test cell can be adjusted against laser beam. Three inclinations $30^{\circ}, 45^{\circ}$ and $60^{\circ}$ are possible to be given to test cell by this mechanism. A $10 \mathrm{~mW}$ He-Ne laser gun (Figure 3) is fitted on rigid horizontal table surface with screw and nut arrangement near one of the optical windows for projecting laser beam of $1.5 \mathrm{~mm}$ diameter through the test cell. Laser gun can be moved along normal axis of test cell. Five identical PT-100 thermal sensors of $0.1^{\circ} \mathrm{C}$ least count are mounted inside the test cell at a distance of $35 \mathrm{~cm}$ from the inlet opening along the same transverse axis at heights $0 \mathrm{~mm}, 10 \mathrm{~mm}, 40 \mathrm{~mm}, 70 \mathrm{~mm}$ and $100 \mathrm{~mm}$ from the absorber surface (Figure 4a). Two Ktype thermocouples have also been mounted for measuring inlet and outlet air temperatures. Thermal gradient obtained by optical method has been compared with the values measured by RTD (PT-100) temperature sensors for validation of optical method.

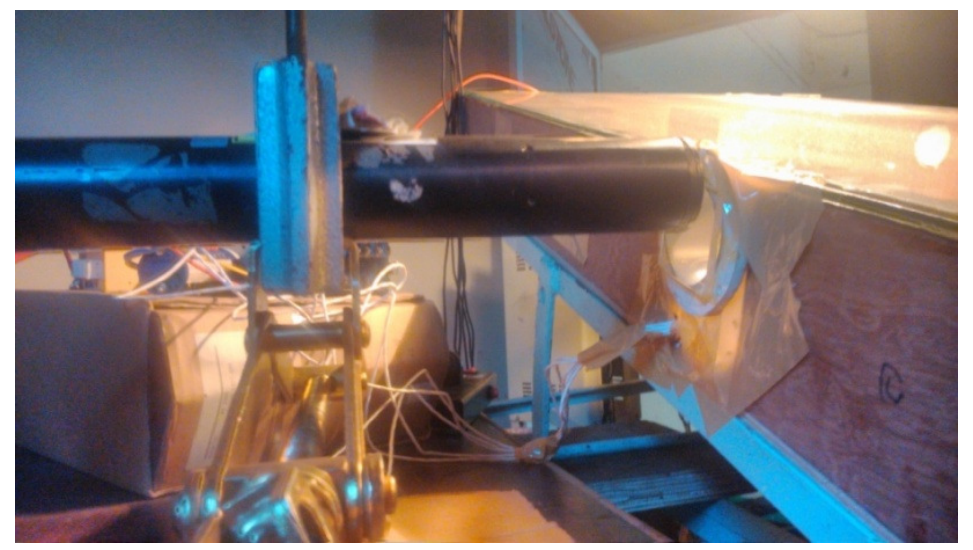

Figure 3. He-Ne laser gun projecting laser through test cell 
A white paper screen along with a micrometer of $0.01 \mathrm{~mm}$ least count is fitted on optical window (Figure $4 \mathrm{~b}$ ) on opposite side of laser gun for minutely measuring laser beam deviation during experimentation.

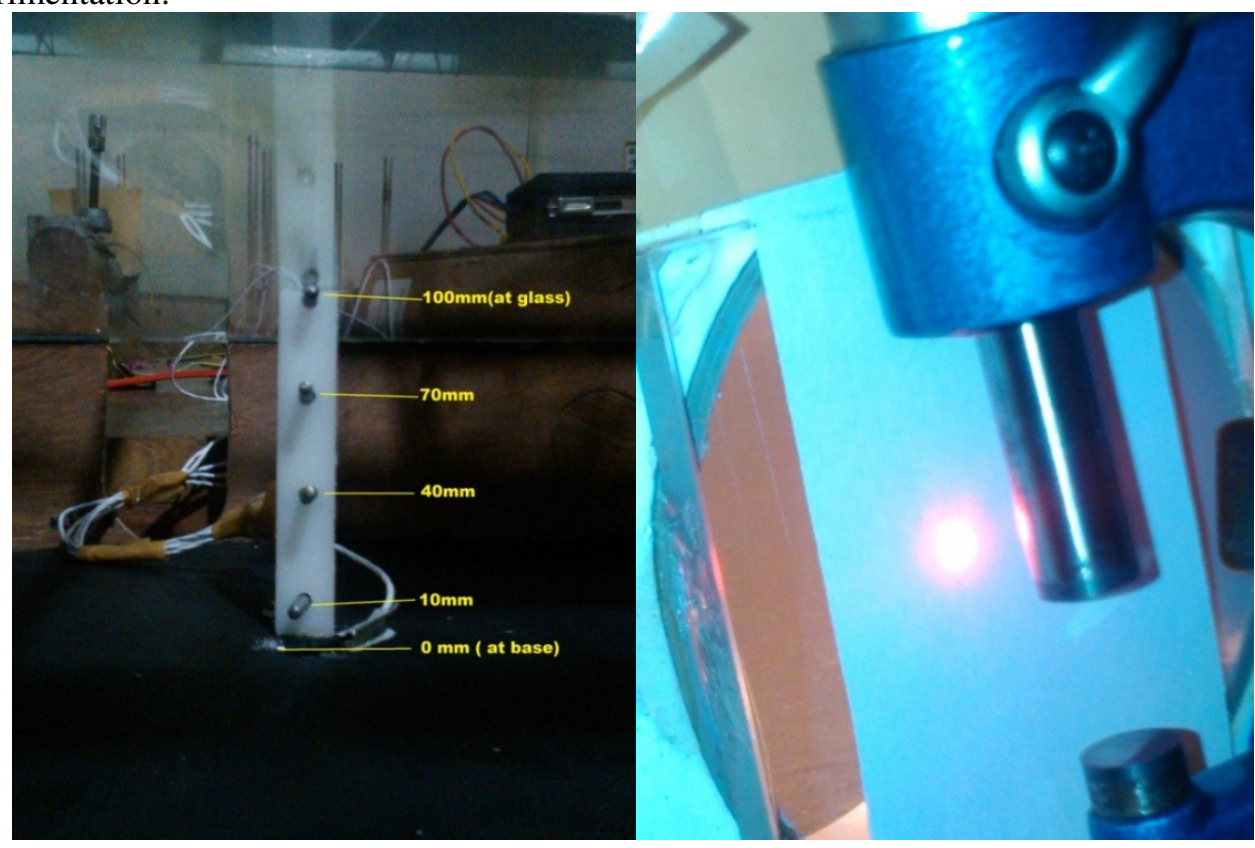

Figure 4(a and b). PT-100 thermal sensors and micrometer

A white paper screen along with a micrometer of $0.01 \mathrm{~mm}$ least count is fitted on optical window (Figure $4 \mathrm{~b}$ ) on opposite side of laser gun for minutely measuring laser beam deviation during experimentation. For simulating solar radiation, a set of six halogen lamps; three of $1000 \mathrm{~W}$ and rest three of 500W arranged in zig-zag manner (Arrangement is depicted in figure 5) has been mounted on a steel frame fitted with traversing mechanism as shown in figure 6 . The reasons for using lamps of two intensities are power supply in the laboratory is unable to handle six halogen lamps of $1000 \mathrm{~W}$ on one hand and intensity of radiation is insufficient if all halogen lamps are of 500W.

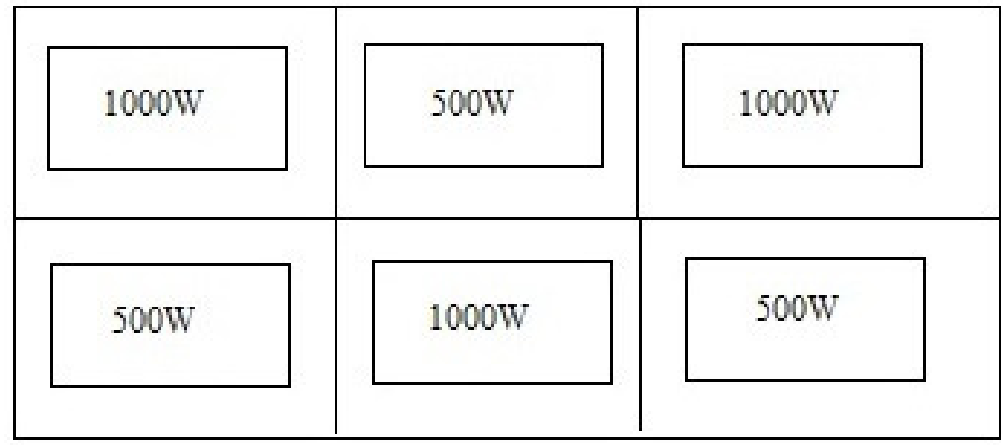

Figure 5. Arrangement of halogen lamps

The 220Volts, $50 \mathrm{~Hz}$, AC electrical power supply to halogen lamps is given through an autotransformer (provides variation in output voltage from 0 to 220 volts) in order to vary radiation intensity. Artificial solar radiation has been calibrated against natural solar radiation intensity values by pyranometer. Halogen lamp frame is kept parallel to transparent cover of test 
cell to ensure normal incidence of radiation on test cell. The distance between test cell top cover and halogen lamps is kept as $18 \mathrm{~cm}$.

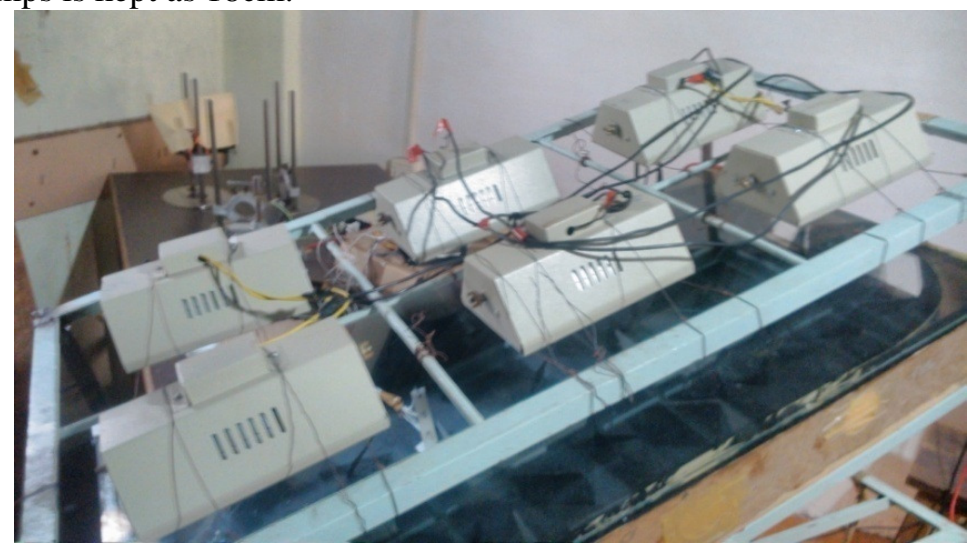

Figure 6. Halogen lamps for artificial solar radiation

\section{DATA REDUCTION}

\subsection{THEORY OF OPTICAL BEAM DEVIATION METHOD}

Peter Mihalka et al [14] have applied a simple experimental method for determining temperature gradient and convective heat transfer coefficient for a vertical heated surface and ambient air with photoelectric technique. Results have also been compared with simulated outcomes by a CFD tool. Authors have applied following theory in the investigation.

Consider convective heat transfer in steady state between a vertical heated surface and surrounding air (Figure 7). The wall surface convective heat flux can be given by the empirical Newton's law.

$$
q=h\left(T_{s}-T_{a}\right)
$$

Where,

$\mathrm{h}=$ convective heat transfer coefficient between air and surface

$\mathrm{T}_{\mathrm{s}}=$ surface temperature

$\mathrm{T}_{\mathrm{a}}=$ ambient air temperature

The same heat flux in steady-state heat flow can be given by the Fourier law of heat conduction

$$
q=-k \frac{d T}{d y}
$$




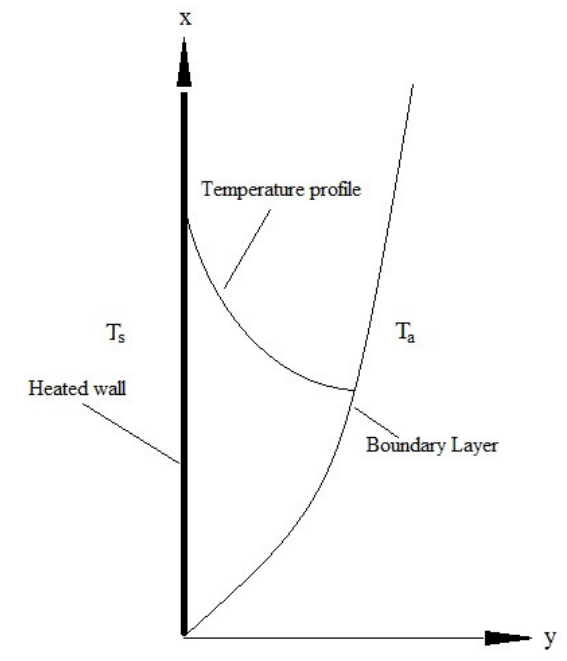

Figure 7. Heat transfer and air flow near heated vertical surface

where $\frac{d T}{d Y}$ is temperature gradient along $\mathrm{y}$-axis and $\mathrm{k}$ is thermal conductivity of air.

Using the equations (1) and (2) the value of convective heat transfer coefficient can be evaluated.

$$
h=\frac{-k \frac{d T}{d y}}{\left(T_{s}-T_{a}\right)}
$$

The experimental determination of the temperature gradient is based on the relationship between the air density dependent on the air temperature and refractive index. This relation is described by the Lorenz-Lorentz law.

$$
\left(\frac{n^{2}-1}{n^{2}+1}\right) \frac{1}{\rho}=\frac{N}{M}=\text { Constant }
$$

Where: $n$ is the air refractive index, $\rho$ is the air density $\left[\mathrm{kg} / \mathrm{m}^{3}\right], N$ is the air molar refraction $\left[\mathrm{m}^{3} / \mathrm{mol}\right], M$ is the air molar mass $[\mathrm{g} / \mathrm{mol}]$

The refractive index for a wavelength is a function of the air density.

$$
n=f(\rho)
$$

Air is assumed to behave as an ideal gas at atmospheric pressure and in the temperature range of $300-400 \mathrm{~K}$. The dependence between air density and temperature is given by the state equation.

$$
\frac{p V}{T}=R \text { i.e. } \rho=\frac{p M}{R T}
$$

where: $p$ is the air pressure $[\mathrm{Pa}], T$ is the absolute temperature $[\mathrm{K}], V$ is the air molar volume $\left[\mathrm{m}^{3} / \mathrm{mol}\right]$ and $R$ is the universal gas constant $[\mathrm{J} / \mathrm{kgmol} . \mathrm{K}]$. Under the assumption of isobaric condition, the air density change is proportional inversely to the temperature change, then the refractive index variation is proportional to the air temperature change. 


$$
\left(\frac{n_{o}-1}{n-1}\right)=\frac{\rho_{o}}{\rho}=\frac{T}{T_{o}}
$$

Where, $\mathrm{n}_{\mathrm{o}}, \rho_{\mathrm{o}}$ and $\mathrm{T}_{0}$ are refractive index, density and temperature of air at $0^{\circ} \mathrm{C}$.

A constant can be found for the relationship between air temperature change and refractive index change for the wavelength of $650 \mathrm{~nm}$ (laser beam) at the temperature of $300 \mathrm{~K}$. B. Gebhart et al [15]

$$
\frac{d n}{d T}=0.961 \times 10^{-6}
$$

Then, the mutual relationship between the refractive index gradients and temperature gradients is as follows. B. Gebhart et al [15]

$$
\frac{d T}{d y}=\frac{1}{0.961 \times 10^{-6}} \frac{d n}{d y}
$$

Considering the constant distribution of refractive index along the path of optical detection by laser beam and appropriate geometrical relations, a final equation for beam deviation is as follows.

$$
\frac{d n}{d y}=\frac{2 n_{o} \Delta y}{L^{2}}
$$

where, $L$ is the laser beam path length $n_{0}$ is the refractive index $=1.0$ for air, $\Delta y$ is the laser beam deviation. By measuring laser beam deviation in a thermal field and with use of the equations (9) and (10) the temperature gradient can be evaluated.

\section{RESULTS AND DISCUSSION}

\subsection{TESTING OF BASIC DESIGN OF SOLAR AIR HEATER (WITH PLANE ABSORBER)}

In this research work, solar air heater fitted with plane absorber surface is considered as basic design of test cell. Experimental work was started with testing the basic design of solar air heater (fitted with plane absorber surface) with solar radiation intensity of $600 \mathrm{~W} / \mathrm{m}^{2}$ and inclination of $30^{\circ}$ under natural convection condition. Thermal performance of test cell was observed with varying air mass flow rate by changing air outlet opening area with shutter. All the observations were recorded in steady state condition, which was established by ensuring constant air outlet temperature. It has been observed that the thermal flow field transients inside the test cell took approximately 75 minutes to die down and establishes steady state condition. Temperatures measured by K-type thermo couples and RTD-PT-100 sensors were recorded manually. Variation in overall thermal efficiency and temperature rise for variation in air mass flow rate were recorded for solar radiation intensity of $600 \mathrm{~W} / \mathrm{m}^{2}$ (Table 1). The calculation of overall thermal efficiency is performed as follows. Velocity of air was measured at outlet openings by anemometer of $0.1 \mathrm{~m} / \mathrm{sec}$ resolution and density of air (for calculating its mass flow rate) was calculated at air outlet temperature assuming steady flow through test cell.

$$
\eta=\frac{m c_{p}\left(T_{o}-T_{i}\right)}{I A_{c}} \times 100 \%
$$


Table 1: Overall Thermal Efficiency vs. Air mass flow rate

\begin{tabular}{|c|c|c|c|}
\hline $\begin{array}{c}\text { Air mass flow } \\
\text { rate }(\mathbf{g m} / \mathbf{s e c} .)\end{array}$ & $\begin{array}{c}\text { Temperature } \\
\text { Rise }\left(\mathbf{T}_{\mathbf{0}}-\mathbf{T}_{\mathbf{i}}\right)^{\circ} \mathbf{C}\end{array}$ & Outlet area $\left(\mathbf{m}^{\mathbf{2}}\right)$ & $\begin{array}{c}\text { Thermal } \\
\text { Efficiency } \\
\mathbf{\%}\end{array}$ \\
\hline 0.695 & 30 & 0.0065 & 6.99 \\
\hline 0.7428 & 27 & 0.00146 & 6.72 \\
\hline 0.784 & 29 & 0.0073 & 7.62 \\
\hline 0.937 & 31 & 0.00438 & 9.74 \\
\hline 0.946 & 27 & 0.00876 & 8.56 \\
\hline 1.093 & 30 & 0.0511 & 10.99 \\
\hline 1.113 & 27 & 0.01022 & 10.07 \\
\hline 1.257 & 30 & 0.0058 & 12.57 \\
\hline 1.261 & 28 & 0.01168 & 11.8 \\
\hline $\mathbf{1 . 3 9}$ & $\mathbf{3 2}$ & $\mathbf{0 . 0 1 3 1 4}$ & $\mathbf{1 4 . 9 1}$ \\
\hline
\end{tabular}

In the natural convection, it has been observed (Table 1) that overall thermal efficiency increases with increase in air mass flow rate and it becomes maximum $(14.91 \%)$ at flow rate of $1.39 \mathrm{gm} / \mathrm{sec}$ and $0.01314 \mathrm{~m}^{2}$ outlet opening area with temperature rise of $32^{\circ} \mathrm{C}$. Further increase in air mass flow rate by operating shutter was not possible in the present configuration. Therefore, this value of overall thermal efficiency has been taken as benchmark for further experimentation on this apparatus. Experiments were repeated with same outlet opening area of $0.01314 \mathrm{~m}^{2}$. Thermal gradient along normal axis of test cell at a distance of $31 \mathrm{~cm}$ from the inlet air openings was also determined by using laser beam deviation method and on the basis of eq. 8, 9 and 10. Laser beam path length (L) is taken as $527 \mathrm{~mm}$ ( width $500 \mathrm{~mm}+$ average of wall and window thicknesses $27 \mathrm{~mm}$ ). Initial readings of micrometer are taken for centre of beam projection on screen at every $5 \mathrm{~mm}$ from the base in off radiation condition. Similarly, final readings are taken under heating (steady state) condition. Differences of final readings and initial readings give the values of laser beam deviation at intervals of $5 \mathrm{~mm}$. RTD (PT-100) thermal sensors have also been used to determine the thermal gradient near the laser beam line at a distance of $35 \mathrm{~cm}$ from the inlet air openings Thermal gradient is assumed to be zero along the laser beam direction. Graphical representation of thermal gradient determined by laser beam deviation method and thermal sensors are shown in figures 8 and 9 respectively.

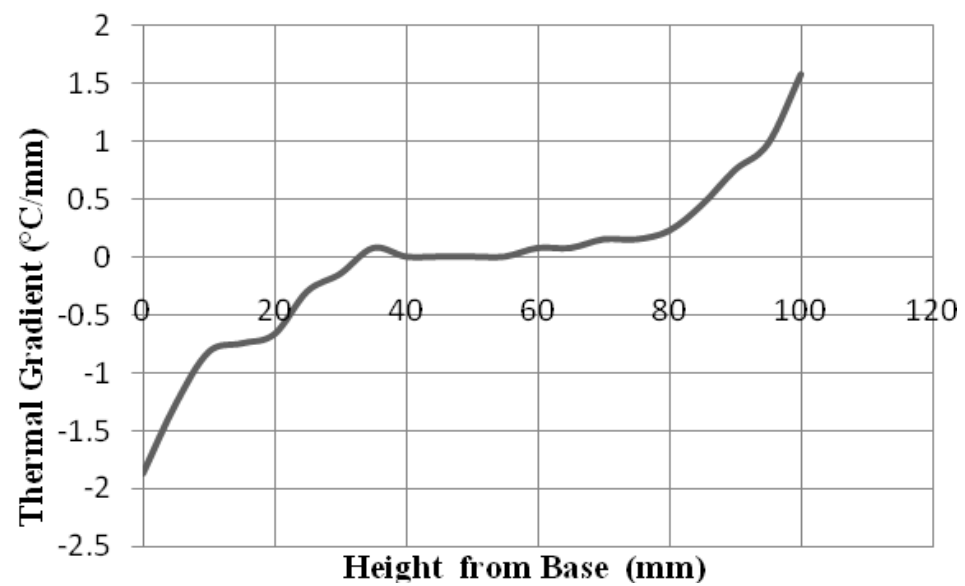

Figure 8. Variation in thermal gradient of basic design of solar air heater at solar intensity of $600 \mathrm{~W} / \mathrm{m}^{2}$ computed by laser beam deviation method 


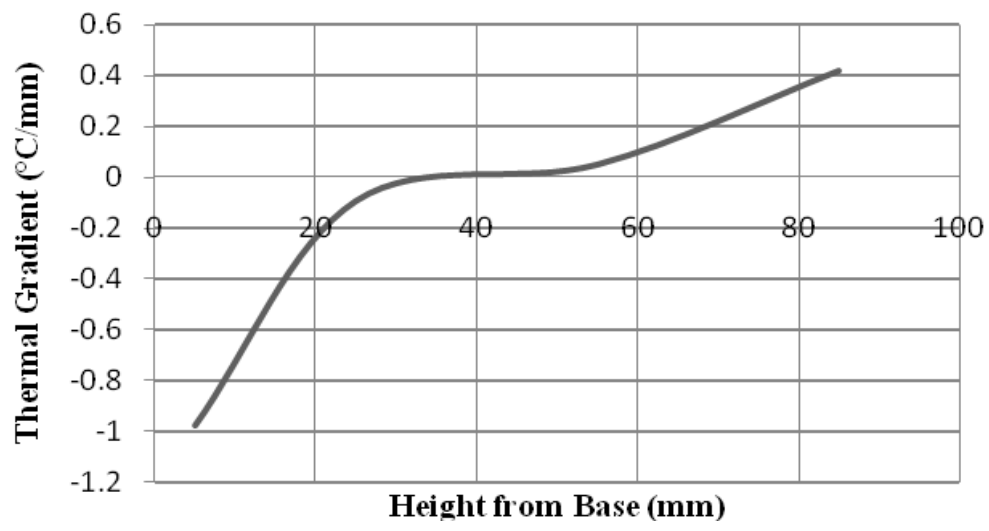

Figure 9. Variation in thermal gradient of basic design of solar air heater at solar intensity of $600 \mathrm{~W} / \mathrm{m}^{2}$ measured by thermal sensors

Good agreement is noticed between optically determined and measured values of thermal gradient variation. The main difference between these methods lies in span of thermal flow field under observation. Laser beam deviation method gives information of thermal gradients for total width of test cell while thermal sensors give thermal gradients along a single normal axis in total width of the thermal flow field. In other words optically determined values of thermal gradients are average of thermal gradients at a height for total width and it is localised for thermal sensors. Secondly, thermal gradient by laser beam deviation method is at every $5 \mathrm{~mm}$ from the base in total $100 \mathrm{~mm}$ height (twenty one values for total $100 \mathrm{~mm}$ height). On the other hand thermal sensors are giving only four values. These points may be behind slight difference in optically determined and measured values of thermal gradients. Both values suggest that thermal gradient changes its sign and is having zero value located near the central portion of thermal flow field. It is almost zero between $25 \mathrm{~mm}$ and $50 \mathrm{~mm}$ heights. It implies that temperature decreases from absorber base surface to centre line and increases from centre to top glass cover. It indicates that thermal flow field around central portion is convection dominated zone. And, convection is weak near boundaries of the field. A significant temperature difference of around $13{ }^{\circ} \mathrm{C}$ between centre and base has been seen in measurement. This indicates that there is low rate of heat transfer between air and boundary surfaces. This can be overcome by attaining more uniform temperature distribution (almost zero thermal gradients) along normal axis of solar air heater. This has been achieved by utilizing a conducting porous medium between boundaries as presented in section 4.2 .

\subsection{TESTING OF SOLAR AIR HEATER (WITH TRANSVERSE V-POROUS RIBS)}

The basic design of solar air heater has now been improvised with five transverse V-porous ribs of blackened aluminium mesh similar to the experiments reported by Arun Venu et al [11] as shown in figure 10 (a) and (b). Mesh is made of aluminium wires of $0.5 \mathrm{~mm}$ diameter and having square openings of $2 \mathrm{~mm} \times 2 \mathrm{~mm}$, while thickness is $0.95 \mathrm{~mm}$. Width of each rib is $8 \mathrm{~cm}$. A gap of $22 \mathrm{~cm}$ is provided between first rib and second rib from inlet side for uninterrupted projection of laser beam and to accommodate thermal sensors. Keeping other conditions same as discussed in section 4.1 , an air mass flow rate of $1.03 \mathrm{gm} / \mathrm{sec}$ is obtained with a temperature rise of $38^{\circ} \mathrm{C}$, which is $6^{\circ} \mathrm{C}$ higher than previous one. Overall thermal efficiency thus calculated is found to be $17.24 \%$ (a percentage increment of $15.62 \%$ ) with this modification in the design. 
International Journal of Recent advances in Mechanical Engineering (IJMECH) Vol.3, No.4, November 2014

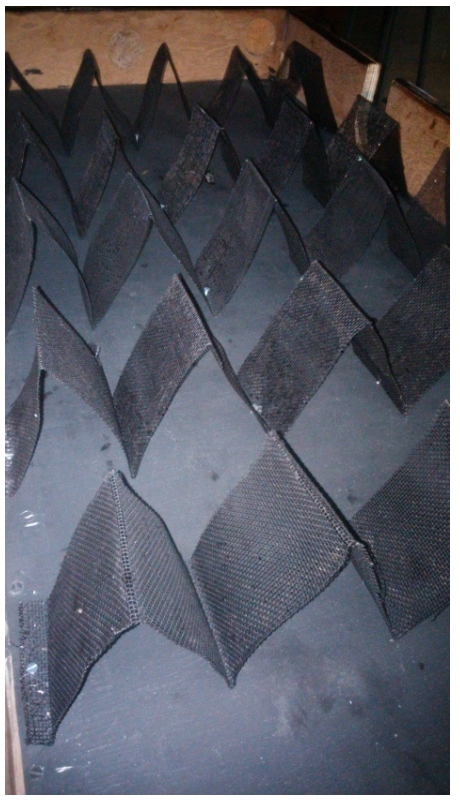

(a)

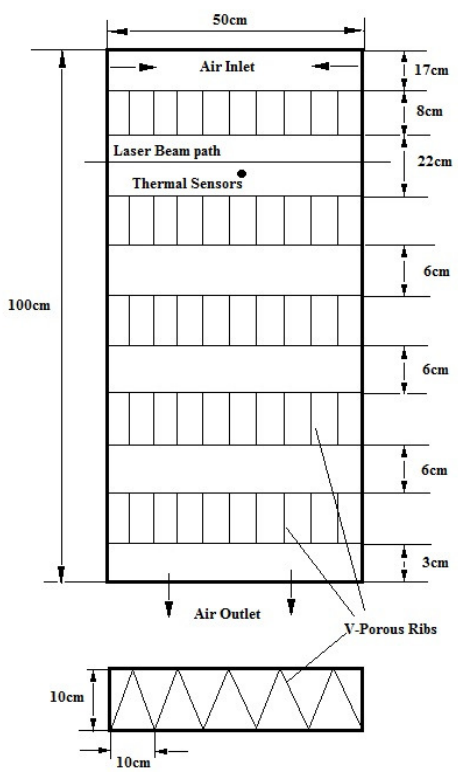

(b)

Figure 10(a) Actual (b) Schematic view inside the Experimental test set up and transverse V-porous ribs.

Variation in thermal gradient along the normal was recorded optically and by thermal sensors with this new arrangement and is shown in figures 11 and 12 respectively.

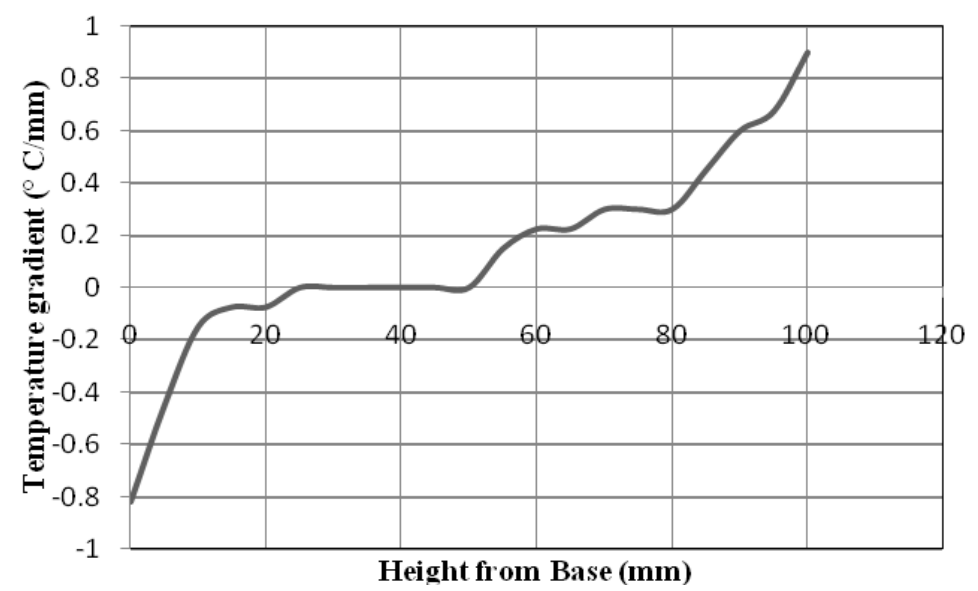

Figure 11.Variation in thermal gradient of solar air heater with transverse V-porous ribs at solar intensity of $600 \mathrm{~W} / \mathrm{m}^{2}$ computed by laser beam deviation method 


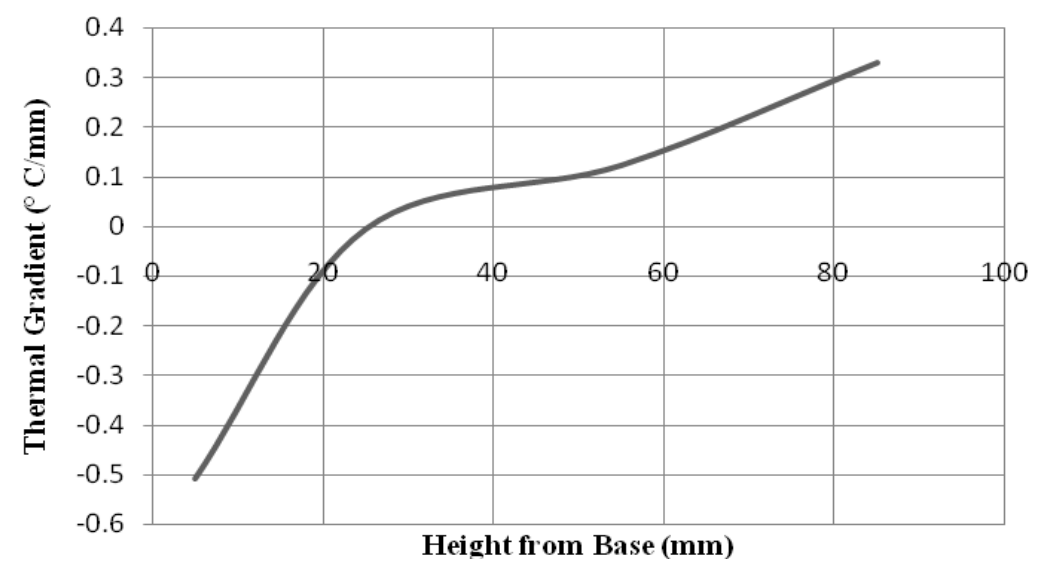

Figure 12. Variation in thermal gradient of solar air heater with transverse V-porous ribs at solar intensity of $600 \mathrm{~W} / \mathrm{m}^{2}$ measured by thermal sensors

Using transverse $\mathrm{V}$-porous ribs, the average thermal gradient of thermal field found to get reduced in both optical and measurement method. When compared with basic design, boundary thermal gradients have been reduced considerably. It is observed that difference in temperatures reduced to $5^{\circ} \mathrm{C}$ between centre and base of test cell. It indicates that air stream at central portion of thermal flow field has strived to attain boundary temperatures because of fall in average thermal gradient. This has increased the temperature rise of air by $6^{\circ} \mathrm{C}$ and in turn percentage rise in overall thermal efficiency to $15.62 \%$. Thus, it can now be concluded that for thermal performance enhancement of solar air heater, there has to have uniform temperature distribution inside the along normal to the base.

\subsection{TESTING OF SOLAR AIR HEATER (WITH INCLINED V-POROUS RIBS)}

Further modification in the previous transverse V-porous rib design has been made with ribs have been fitted in position inclined to the direction of air flow (Figure 13). Total number of ribs is kept constant as five. The ribs are positioned inclined to each other at right angle. This modification is adapted so as to increase the portion of air flowing across the mesh and in turn air can absorb more amount of heat from absorbing surfaces. In the present ecperiments, testing has been conducted under natural convection keeping other conditions same as discussed in sections 4.1 and 4.2. Overall thermal efficiency obtained was $20.04 \%$ with temperature rise of $45^{\circ} \mathrm{C}$ and air mass flow rate of $1.011 \mathrm{gm} / \mathrm{sec}$. Thus a change in design has contributed in percentage rise of $34.4 \%$ in overall thermal efficiency with respect to basic design (first model) and of $16.24 \%$ as compared to transverse $\mathrm{V}$-porous rib design (second model).

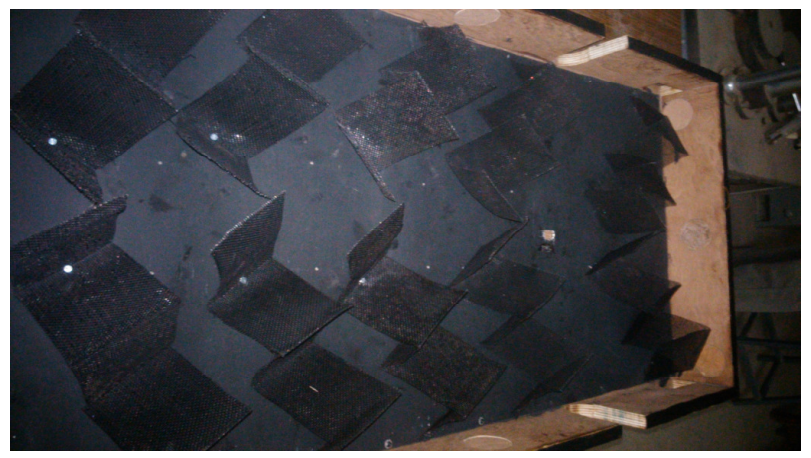

Figure 13. Solar air heater with inclined V-porous ribs 
The results of inclined V-porous ribs obtained optically and by thermal sensors are shown in figures 14 and 15 respectively. Variations in thermal gradient obtained by both the methods are approximately similar to each other. A significant reduction in thermal gradient on the base has been noticed as compared to the transverse ribs. And, small changes are seen on glass cover side. Also in optical results, uniform temperature zone around central portion (zero thermal gradients) has expanded to $60 \mathrm{~mm}$ height from the base. Difference in the temperatures between centre and the base has been reduced to $2^{\circ} \mathrm{C}$ quite remarkable as compared to $13^{\circ} \mathrm{C}$ in first testing. It shows that air has reached close to boundary temperatures in the whole thermal flow field developed inside the test cell. Thus, the overall thermal efficiency of solar air heater has further increased with this modification in the arrangements of experimental test set up.

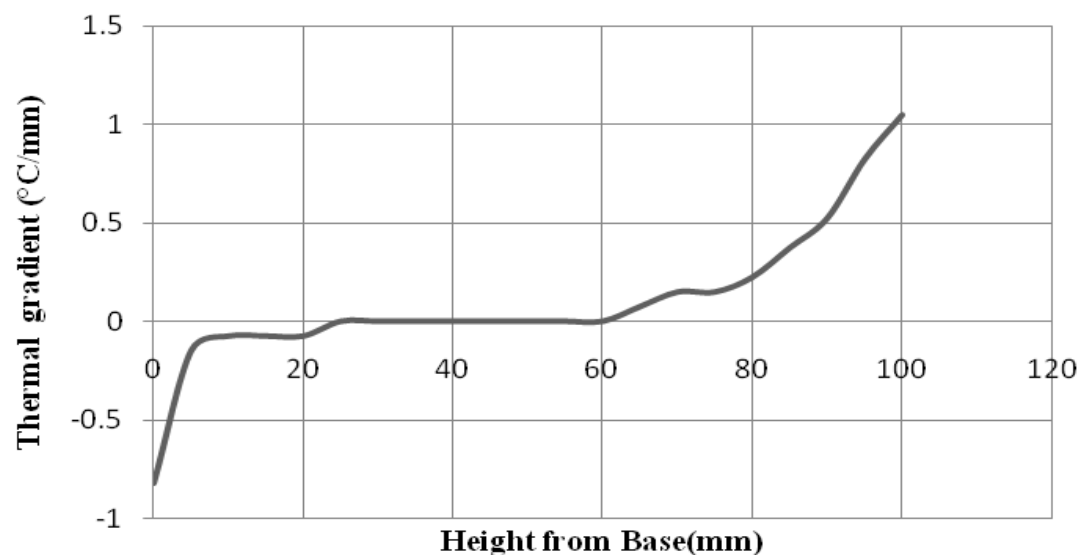

Figure 14. Variation in thermal gradient of solar air heater with inclined V-porous ribs at solar intensity of $600 \mathrm{~W} / \mathrm{m}^{2}$ computed by laser beam deviation method

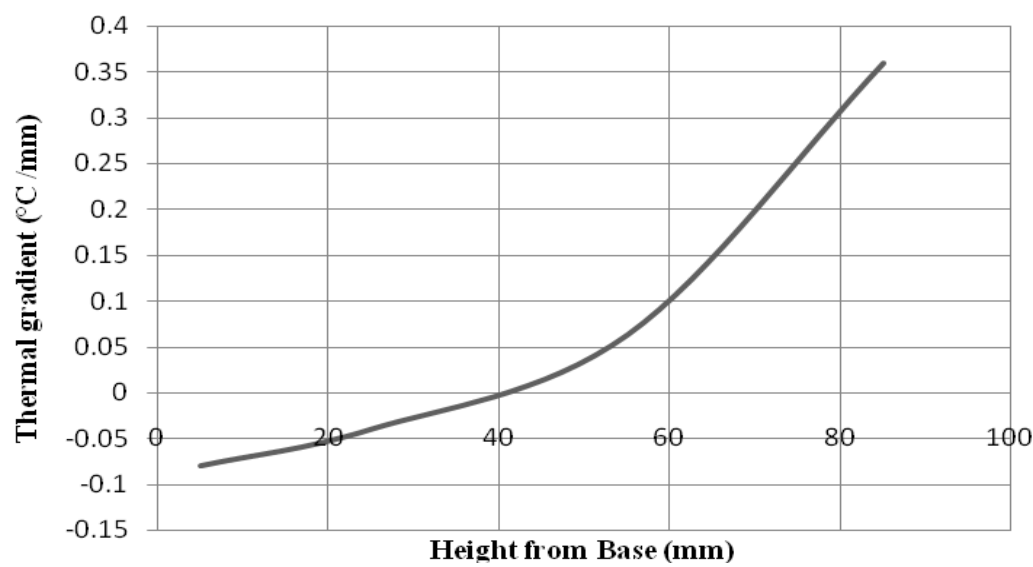

Figure 15. Variation in thermal gradient of solar air heater with inclined V-porous ribs at solar intensity of $600 \mathrm{~W} / \mathrm{m}^{2}$ measured by thermal sensors

\section{CONCLUSiON}

An experimental test set up at laboratory scale has been developed for thermal performance testing of flat plate solar air heater with constant solar radiation intensity; $600 \mathrm{~W} / \mathrm{m}^{2}$ and at $30^{\circ}$ inclination. For this, a solar air heater of size $1 \mathrm{~m} \times 0.5 \mathrm{~m} \times 0.1 \mathrm{~m}$ has been fabricated. Three designs namely (i) plane absorber (ii) plane absorber with transverse V-porous ribs and (iii) plane 
absorber with inclined V-porous ribs of absorber surface have been tested. All the experiments are conducted with artificial and calibrated solar radiation and in natural convection condition. Performances of these three designs have been compared on the basis of overall thermal efficiency and thermal gradient along normal to the base at particular section of the solar air heater. Considering outcomes of experimentation work performed on three designs of solar air heater, the following points could be concluded:

1. A percentage rise of $34.4 \%$ in overall thermal efficiency of solar air heater with respect to the basic design of solar air heater.

2. Thermal gradient normal to absorber surface in the thermal flow field plays an important role in thermal performance of solar air heater.

3. Uniform distribution of temperature along the normal to the absorber surface increases air outlet temperature which results in increasing overall thermal efficiency.

\section{ACKNOWLEDGEMENT}

Authors acknowledge MPCST, Bhopal gratefully for financial support to the research work.

\section{REFERENCES}

[1] Esen Hikmet., (2008) "Experimental energy and exergy analysis of a double-flow solar air heater having different obstacles on absorber plates". Building and Environment., Vol.43 pp 1046-1054.

[2] Moummi N., Youcef-Ali S., Moummi A. and Desmons J.Y., (2004) "Energy analysis of a solar air collector with rows of fins". Renewable Energy., Vol.29, pp 2053-2064.

[3] Chabane Foued, Moummi Noureddine ,Benramache Said, Bensahal Djamel, Belahssen Okba and Lemmadi Fatima Z. , (2013)“Thermal Performance Optimization of A Flat Plate Solar Air Heater". International Journal of Energy \& Technology. Vol.5, No. 8, pp 1-6.

[4] Karwa Rajendra, Panwar O. P. And Maheshwari B.K., (2010) "Performance Study of a Solar Air Heater with Chamfered Rib-roughness on Absorber Plate for Space Heating Applications", Proceedings 20th National And 9th International ISHMT-ASME Heat And Mass Transfer Conference, No.130,pp 463-470.

[5] Hans Vishavjee Singh, Saini R.P. and Saini J.S., (2010) "Experimental investigation of heat transfer and friction characteristics of a multiple V-rib roughened solar air heater." Proceedings 20th National and 9th International ISHMT-ASME Heat and Mass Transfer conference. No.152,pp546-551.

[6] Chand Prabha and Sharma S.P., (2010) "Thermal Performance Prediction Of Extended Absorber Solar Air Heater". Proceedings 20th National and 9th ISHMT-ASME Heat and Mass Transfer conference. No.289, pp 1120-1124.

[7] Koyuncu Turhan., (2006) "Performance of various design of solar air heaters for crop drying applications". Renewable Energy., Vol.31, pp 1073-1088.

[8] Moummi N., Youcef-Ali S., Moummi A. and Desmons J.Y., (2004) "Energy analysis of a solar air collector with rows of fins". Renewable Energy., Vol.29, pp 2053-2064.

[9] Esen Hikmet., (2008) "Experimental energy and exergy analysis of a double-flow solar air heater having different obstacles on absorber plates". Building and Environment., Vol.43 pp 1046-1054.

[10] Chabane Foued, Moummi Noureddine and Benramache Said., (2013) "Experimental analysis on thermal performance of a solar air collector with longitudinal fins in a region of Biskra, Algeria". Journal of Power Technologies, Vol.93 (1), pp 52-58.

[11] Venu Arun and P Arun.,(2013)“ Simulation Studies on Porous Medium Integrated Dual Purpose Solar Collector". International Journal of Renewable Energy Research, Vol.3 No.1, pp 114-120.

[12] Romdhane Ben Slama., (2007) "The air solar collectors: Comparative study, introduction of baffles to favor the heat transfer". Solar Energy. Vol.81, pp139-149.

[13] Solanki S.C., Dubey swapnil, and Tiwari Arvind.,(2009) “Indoor simulation and testing of photovoltaic thermal (PV/T) air collectors”. Applied Energy,. Vol.86, pp 2421-2428. 
[14] Mihalka Peter, Drzik Milan and Matiasovsky Peter.,(2007) "Mesurement Of Local Convective Surface Heat Transfer Coefficient By Photoelectric Method". Proceedings of Thermophysics, Bratislava, Vyadavatelstvo STU, ISBN-978-80-227-27465-4, pp 86-92.

[15] Gebhart B.,Jaluria Y., Mahajan R.L. and Sammakia B. (1988) "Buoyancy-Induced Flows and Transport.” Book, Hemisphere Publishing Corporation, New York.

\section{Authors (Short Biography)}

\section{First Author}

\section{Santosh Vyas}

Associate Professor and Head.

Department of Mechanical Engineering,

Mahakal Institute of Technology and Science, Ujjain (MP), India

Registered for PhD in RGPV Bhopal Under the supervision of Dr. Sunil Punjabi, Associate Professor, UEC, Ujjain. Topic:- Design Optimization of Solar Dryer,

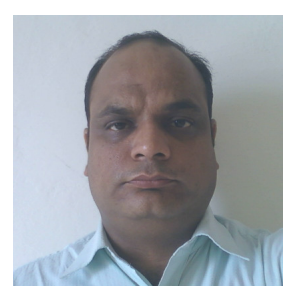

(Work is approved and funded by MPCST, Bhopal).

\section{Professional Experience}

Aug'1999-July 2000 Contract Lecturer, Department of Mechanical Engineering, Government Polytechnic, Jaora (MP)

Oct' 2001-July2007 Lecturer, Department of Mechanical Engineering, MIT, Ujjain (MP)

July 2007- March 2011 Reader, Department of Mechanical Engineering, MIT, Ujjain (MP)

April 2011-April 2012 Associate Professor, Department of Mechanical Engineering, AIT, Ujjain (MP)

April 2012-Janaury 2013 Associate Professor and Head, Department of Mechanical Engineering, Oriental University, Indore.

January 2013-Present Associate Professor and Head, Department of Mechanical Engineering, MITS Ujjain (MP).

Research Experience

Involved in engineering research work for last five years in the area of thermal and fluid engineering and application of research work is solar thermal systems.

\section{Second Author}

\section{Dr. Sunil Punjabi}

Associate Professor

Department of Mechanical Engineering,

Ujjain Engineering College, Ujjain (MP) India

$\mathrm{PhD}$ (Fluid and Thermal Engineering), from Department of Mechanical Engineering,

Indian Institute of Technology, Kanpur, India. Topic: Experimental Study of Convection in Differentially Heated Fluid Layers using Laser Interferometry. Under the supervision of Dr. K. Murlidhar, Professor and Dean (R\&D), IIT Kanpur and Dr. P.K. Panigrahi, Professor, IIT Kanpur.

Post-Doctoral Fellow: Department of Fluid Mechanics and Heat Transfer, Faculty of Engineering, Tel Aviv University 69978 Tel Aviv, Israel. Research Field: Turbulent mixing layer around wind tunnels using optical instrumentation technique combined with hot wire anemometer. Advisers: Prof. E, Kit and Dr. Alexander Gelfgat.

Principal Investigator in Research Project of Madhya Pradesh Council of Science and Technology, Bhopal at Ujjain Engineering College, Ujjain. 
Publications: More than 15 papers have been published in national and international conferences and journals.

Book Review work: Computerized Tomography for Scientists and Engineers ( Taylor and Francis (USA) and Anamaya (India).One chapter on Convection in differentially heated fluid layers and its reconstruction using radial tomography in an octagonal cavity.

\section{Keynote Lecture}

"Influence of layer height on a buoyancy-driven convection in differentially heated superimposed fluid layers confined in a rectangular cavity." $14^{\text {th }}$ international Conference on Computational and Experimental Engineering and Sciences, Miami, Florida, USA. 